University of Windsor

Scholarship at UWindsor

Winter 2015

\title{
Ease of Use and Usefulness as Measures of Student Experience in a Multi-Platform E-Textbook Pilot
}

\author{
Dave Johnston \\ University of Windsor \\ Selinda Berg \\ University of Windsor \\ Karen Pillon \\ University of Windsor \\ Mita Williams \\ University of Windsor
}

Follow this and additional works at: https://scholar.uwindsor.ca/leddylibrarypub

Part of the Scholarly Publishing Commons

\section{Recommended Citation}

Johnston, Dave; Berg, Selinda; Pillon, Karen; and Williams, Mita. (2015). Ease of Use and Usefulness as Measures of Student Experience in a Multi-Platform E-Textbook Pilot. Library Hi Tech, 33 (1), 65-82.

https://scholar.uwindsor.ca/leddylibrarypub/33

This Article is brought to you for free and open access by the Leddy Library at Scholarship at UWindsor. It has been accepted for inclusion in Leddy Library Publications by an authorized administrator of Scholarship at UWindsor. For more information, please contact scholarship@uwindsor.ca. 


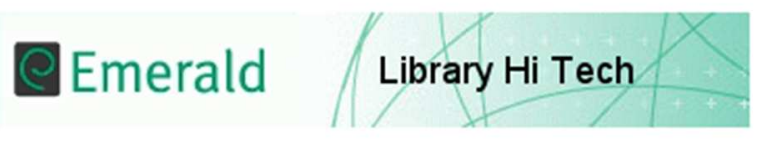

\section{Ease of Use and Usefulness as Measures of Student Experience in a Multi-Platform E-Textbook Pilot}

\begin{tabular}{|r|l|}
\hline Journal: & Library Hi Tech \\
\hline Manuscript ID: & LHT-11-2014-0107.R2 \\
\hline Manuscript Type: & Original Article \\
\hline Keywords: & $\begin{array}{l}\text { Electronic textbooks, Technology acceptance model, Electronic resources, } \\
\text { Universities, Students, Technology adoption }\end{array}$ \\
\hline \multicolumn{2}{|c}{} \\
\hline
\end{tabular}

\section{SCHOLARONE $^{m}$ \\ Manuscripts}




\title{
Ease of Use and Usefulness as Measures of Student Experience in a Multi-Platform E-Textbook Pilot
}

First Published in Library Hi Tech - 2015, vol. 33 iss. 1

Dave Johnston, Selinda Adelle Berg, Karen Pillon, Mita Williams ${ }^{a}$

${ }^{a}$ Leddy Library, 301 Sunset Avenue, University of Windsor, Canada

\begin{abstract}
As the use of electronic textbooks continues to expand and we approach the point where dominance of digital over print is becoming increasingly inevitable (Reynolds, 2011), research is needed to understand how students accept and use the technology. This is especially critical as we begin to explore the electronic format for required textbooks in higher education. The current study evaluates university students' experiences with electronic textbooks (e-textbooks) during a pilot project with two textbook publishers, Flat World Knowledge (FWK) and Nelson Education (Nelson). Using the Technology Acceptance Model (TAM) as a framework, we examine the perceived ease of use and perceived usefulness of the technology. While previous research suggests that students have a general preference for textbooks in print rather than electronic format (Allen, 2009; Parsons, 2014; Woody, et al., 2010), our study suggests that preference may not dictate the likelihood that students will seek out and use print options. Our study also indicated that student experience with the open/affordable textbook (FWK) was very comparable to that of the high cost commercial text (Nelson). Despite overall positive reviews for the etextbooks across both platforms, students experienced a drop in enthusiasm for e-textbooks from the beginning to the end of the pilot.
\end{abstract}

\section{Introduction}


Textbooks have been a standard tool for learning in universities and colleges for more than two centuries; however, in the last decade the fate of the physical textbook has been questioned. While print is currently the dominant format in the textbook marketplace, the emerging environment is supporting a shift towards electronic textbooks (e-textbooks). The current state of technology, the publishing industry and student technological aptitude is threatening to move the print textbook into obsolescence. The body of literature addressing the potential of e-textbooks highlights cost savings, portability and unique digital features that are not possible with their print counterparts as potential benefits of e-textbooks (Sun, Flores and Tanguma, 2012). In response to the possibility that e-textbooks could replace print texts as the primary means of textbook delivery in post-secondary education, libraries, bookstores and publishers are aggressively pursuing the possibilities of their roles in this market (Lyons and Hendrix, 2014; de Oliveria, 2012).

Using the Technology Acceptance Model (TAM) as a framework for analysis, the current study provides insight into the broader understanding of students' perceptions of electronic textbooks' usefulness and ease of use as a guide to understand students' use of electronic textbooks. The study reports on a pilot project of eleven university classes adopting electronic textbooks by two electronic textbook publishers, Flat World Knowledge (FWK) and Nelson Education.

\section{Literature Review}

Until recently, electronic book adoption in the academic context was limited to e-books available via the library to support student and faculty research (Berg, et al., 2010), however, universities are now starting to explore the electronic format for textbooks. Since the use of ebooks is transitioning from an (optional) research tool to a (required) textbook, an even greater 
understanding of the way in which students use and accept electronic texts is necessary in order to ensure students have a positive and successful learning experience.

The corpus of research on the use of e-books reports numerous potential benefits of ebook adoption including: reduced costs, potential portability, accessibility on a variety of platforms, and the integration of features which are not possible in print books such as audio and video, in text linking, and full text searching (Internet2, 2012; Berg, et al., 2010). Faculty and students have begun to take advantage of the potential benefits that e-books offer in an academic research context (Shelburne, 2009), however over recently has the application of e-books began migrating to the textbook market (Blummer and Keaton, 2012). For publisher's, textbook sales are limited by students ability to find alternative ways of accessing their course readings (Lyons and Hendrix, 2014). Subscription pricing of e-textbooks at the institutional level can enable publishers to maximize buy in (CourseSmart, 2013).

The potential shortcomings of e-textbook use in higher education are also discussed widely in the literature. First, faculty members are not always comfortable with implementing many of the new features provided by e-textbooks such as note sharing, tracking student use, and quizzes (Internet2, 2012). Further, early studies suggested that students may not be ready to abandon print for electronic texts (Sheppard, et al., 2009). The hesitation towards adopting electronic texts is often attributed to readability issues in the electronic format. Previously published literature highlights differences in behaviour when reading on a screen and reading in print (Robinson, 2011) as well as potential issues related to eye fatigue (Jeong, 2010). While readability continues to be perceived as a potential barrier, the emergence of new technological devices like the iPad and Kindle may have the potential to "sweep away any lingering doubts about whether students will actually embrace reading from a screen" (Chesser, 2011). 
More specific concerns have been raised about the ability for all individuals to use etextbooks effectively. The National Federation of the Blind raised concerns that the Internet2 etextbook pilot involving five American institutions was "preventing blind and print-disabled students from fully participating" (CampusTechnology, 2012). As a result, the University of Minnesota withdrew from program.

More recently, Foasberg (2014) published the results of a qualitative study of college students' reading habits with regard to print and electronic formats. The findings suggested that while students make use of both print and electronic sources, students use the print format more frequently for long-form reading and tend to engage with print more deeply than electronic resources. These findings have important ramifications on e-textbook adoption. Students were far more likely to annotate print materials rather than electronic and students in the study expressed frustration that they could not interact with e-textbooks in the same was as they did with print. Overall, electronic books were used for selected academic purposes, but more often electronic books were used for shorter and non-academic reading (Foasberg, 2014). Foasberg clarifies:

Despite the ever-increasing popularity of new ways of reading, the study participants read in a fairly traditional way. Most of them preferred to use print for long-form and academic reading, at least partly because they felt more comfortable annotating documents in a print environment. They read electronically a great deal, but this reading consisted primarily of brief, nonacademic materials...Their dislike of electronic textbooks was especially striking. (Foasberg, p. 24)

Foasberg's results seem to indicate that students' preference for print for academic use will impede adoption of e-textbooks for academic purposes.

One factor influencing the adoption of e-textbooks highlighted by Foasberg (2014) is cost. The high price of print textbooks is challenging for students so unsurprisingly numerous authors have identified cost as a crucial consideration in e-textbook adoption. Textbooks can 
account for a large proportion of student educational expenditures and debt (Hilton III et. al, 2014). Students actively work to minimize the impact that textbooks' high prices have on their often limited budgets by finding alternative ways to access the text, be it buying used, sharing, or even piracy (Lyons and Hendrix, 2014). While students would welcome a cost-savings, it is unclear if the electronic format truly has the potential to provide textbooks at a reduced cost. While there are multiple projects examining the potential for free or affordable e-textbooks for students (Baker, 2009), many publishers are offering the electronic format for the same exorbitant price as the print textbooks. Further, students' ability to resell their textbooks is a source of revenue for students (Simba Information, 2012) and e-textbooks may prevent resale.

\section{Technology Acceptance Model}

The factors influencing the acceptance and rejection of new technologies have been of interest to scholars for decades. One of the most popular models that attempt to capture the acceptance or rejection of technologies in the workplace is Davis's Technology Acceptance Model (Davis, et al., 1989). The purpose of the Technology Acceptance Model (TAM) was to explain how users decide to accept and use a technology. The model in its initial and simplest form the model focused on two primary factors: 1.) ease of use, defined as "the degree to which a person believes that using a particular system would be free from effort" and 2.) perceived usefulness defined as "the degree to which a person believes that using a particular system would enhance his or her job performance" (Venkatesh, et al., 2003, p. 448) (Figure 1). Multiple revisions of the model have been proposed to the TAM, including the TAM2 and TAM3, however, the original TAM continues to dominate and be applied more than 25 years after its inception (Edmunds et al., 2012; Shih et al., 2011; Shroff, et al., 2011). 


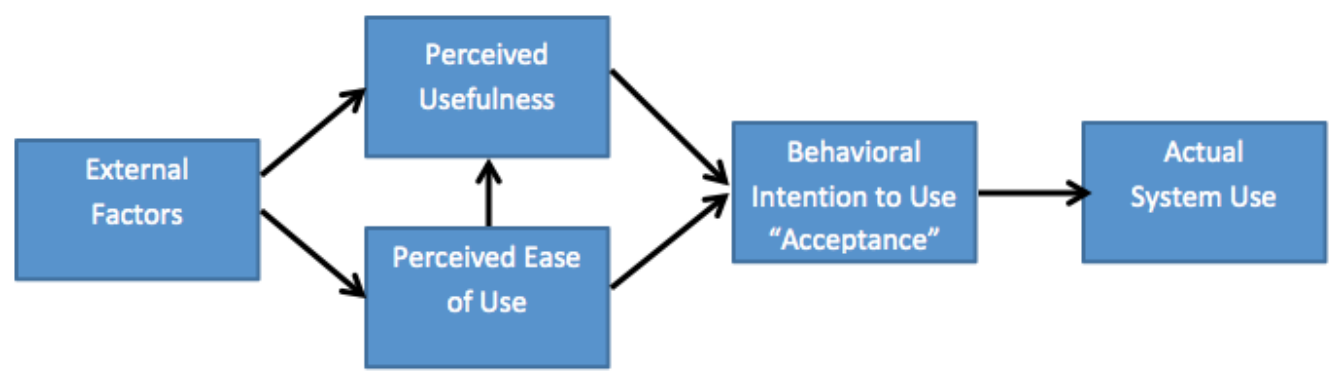

Figure 1: Original Technology Acceptance Model (TAM). Adapted from: Davis et al. (1989)

The TAM suggests that these two factors are key in determining the uptake of technology:

TAM proposes that two particular beliefs, perceived usefulness and perceived ease of use, are the primary drivers for technology acceptance. Further, perceived usefulness and perceived ease of use both affect a person's attitude toward using the system. (Davis and BaLee, 2010, 508)

TAM has been applied and validated in numerous settings and situations beyond the workplace, including in educational settings (Edmunds, et al., 2012; Shroff, et al., 2011). While the TAM provides researchers with the validated tools to apply scales to assign a quantitative prediction of the likelihood that a technology will be adopted, the current study uses the model only as a framework to frame the scope of the questions and the study.

\section{Context of Research Project}

The current study captures a two-year pilot project at the University of Windsor which aimed to evaluate the feasibility of multiple models for provide students with access to electronic textbooks. The multi-faceted pilot project is led by the library at the University of Windsor and is funded by the University's strategic initiatives fund which enabled us to provide a free eTextbook for each student enrolled in one of the participating classes. The complimentary textbook for students was an important element of our pilot as it allowed the researchers and students to focus on the usefulness and ease of use of the technology without being mired by the cost of the textbook. The current publishing models for textbooks are complicated and students 
have a variety of ways to access and engage with e-textbooks including digital purchases, short term rentals, and even more affordable access through negotiated licenses (Lyons and Hendrix, 2014).

The library's mandate was to build a pilot to provide complimentary textbooks to all students in classes that participated in the pilot. Both open access textbook providers as well as traditional commercial publishers were to be piloted, however, during the study the open access publisher transitioned away from a fully open model. Both publishing models were selected for the study because each format has both benefits and drawbacks. Open access is an attractive option for students who often struggle to manage the cost of textbooks, as well as the support of open access initiatives aligns with the library's core values. In contrast, traditional publishers can provide access to large libraries textbooks already in use by faculty members and do not require curricular change.

Flat World Knowledge. The pilot's initial open access partnership was with publisher, Flat World Knowledge (FWK). FWK provided web-based versions of the textbook were available for free online for all potential users. In addition to the free online version of the textbook, through funding for the pilot, all students in the course were provided with FWK's Digital All-Access Pass (The cost of $\$ 34.95 \mathrm{Cdn}$ was covered by the funding for the pilot). The Digital All-Access Pass provides users with the option of several downloadable textbook formats such as PDF, ePub, and Mobi files that can be read on digital readers (iPad, Kindle and Nook) as well as access to supplemental learning materials made available by FWK such as quizzes and flashcards. During the course of the study, FWK departed from the model which provides free access to an online version of the textbook (Howard, 2012) and as a result can no longer be considered an open access textbook provider. Because student access to the textbooks and all- 
access pass was funded by the project, the transition of business models did not affect our study.

Despite the transformation of FWK away from an open-access publisher, FWK remains an inexpensive alternative to traditional textbook publishers and the company has affirmed their commitment to affordable textbook provision.

In order to ensure students were not disadvantaged by limiting their access to only the electronic format, several options for print versions of the textbook were made available to students including printing capabilities for PDFs of individual chapters, purchase of the full print textbook through the university bookstore, and print-on-demand orders could be placed through FWK for the price of $\$ 20 \mathrm{Cdn}$.

Nelson Education. The library's commercial publishing partner was Nelson Education (Nelson) using the VitalSource e-textbook delivery platform. One of the key benefits of working with the Nelson was that faculty partners were very interested in participating in the pilot because Nelson has an extensive body of textbook titles. Some faculty members were already using Nelson titles that were available electronically and therefore were able to maintain their current textbook while participating in the pilot. Nelson allows users to access textbooks in three ways: online with a web browser, on a mobile device, or by downloading books for offline use to the VitalSource Bookshelf platform. Notes and highlights are automatically synced with user accounts and are visible no matter where they read from. The offline VitalSource Bookshelf does contain digital rights management (DRM) that requires you to redeem a code to read your book. The DRM prevents the book from being read outside of this platform on external formats like PDF. Users are also limited to printing 10 pages at a time. Traditional print copies of the Nelson texts could be purchased at prices ranging from $\$ 100-\$ 180 \mathrm{Cdn}$.

Through the pilot, the current study aimed to answer the following research questions: 
1.) How do students perceive the ease of use of electronic textbooks?

2.) How do students perceive the usefulness of electronic textbooks?

3.) How do students' experiences with electronic textbooks differ from print textbooks?

4.) What differences emerge, if any, when the two publishing platforms are compared?

5.) How does students' enthusiasm towards electronic textbooks evolve from their initial introduction to their actual use?

\section{Methods:}

Students included in the study were enrolled in one of 11 classes taking part in the pilot The classes included were in the areas of business, psychology, labour studies, and statistics (see Table 1). The study took place across six semesters and included five unique courses. Given the funding received from the university's strategic priorities fund, we were able to provide all students in the pilot with a free e-textbook for their course. In total, students in 11 classes were recruited to the study. A total of 871 students were enrolled in the 11 classes (Table 1). Recruitment was done during one of the final classes of the semester when researchers visited each class in person. At this time, the researcher provided students with printed copies of the Letters of Information, and an invitation to take part in the research. Students were provided time during the class to complete the online survey. The questionnaire included questions related to: a.) demographic information b.) their perceived usefulness of the electronic format, c.) their perceived ease of use of the electronic textbooks d.) and their general habits with the textbook including how their experiences compare to print. The questionnaire contained both close-ended and open-ended questions and took an average of 6 minutes to complete. The current study received clearance from the University of Windsor's Research Ethics Board.

(Table 1: Courses, Textbooks, and Response Rate) 


\section{RESULTS}

\section{Characteristics of Respondents}

Of the 871 students enrolled across the 11 classes, the total response rate was $48 \%$ ( $n=416)$. Full information about the individual classes, textbooks, and response rate is available in Table 1. Demographic data provided by the student was evaluated to ensure that the respondents accurately reflected the student population of the courses (See Table 2).

(Table 2: Respondent Demographics)

In order to gain an understanding of students' general comfort with technology, respondents were asked to indicate their level of comfort with computer technologies as comfortable (1), somewhat comfortable (2), or not at all comfortable (3). The overall mean level of comfort was 1.35 , with the majority (68.3\%) of students reporting being comfortable with technology. Less than 5\% of individuals reported being not at all comfortable with technology. The level of comfort of students' from the two faculties (Business and Social Science) were compared using a chi-square analysis. Students in the Faculty of Business were significantly more likely to report a lower level of comfort with technology than those in the Faculty of Social Sciences $\chi^{2}(2, N=412)=0.248, p=.00$.

(Table 3: Reported Level of Comfort with Technology)

Students were also asked to indicate on what type of device that they were most likely to access the electronic textbook. The vast majority $(72.4 \%, \mathrm{n}=301)$ of respondents indicated that they were most likely to access the textbook on a personal laptop. Tablet or home desktop computers were the next most popular type of device to access the textbook (10.3\% and $12.9 \%$ 
respectively). A very small number of students accessed the textbook primarily on a e-reader or lab/library computer (4 students and 2 students respectively). The results were very similar between the two faculties, with the exception that a slightly larger percentage of students (16.6\%) from the Faculty of Social Sciences primarily accessed the textbook on a tablet than those from Business (7\%).

\section{Factors Influencing Purchase of Textbooks}

In order to better understand the factors influencing the likelihood that students would purchase a textbook for their classes, students were asked to rate the importance of six factors (Table 4) from 1 (not at all important) to 4 (very important). Results indicate that the most important factor influencing students purchase of textbooks was the requirement by the professor (mean=3.36, $\mathrm{SD}=7.09$ ), followed closely by the cost of the textbook (mean=3.20, $\mathrm{SD}=.898$ ). The least important factors influencing students' decision to purchase were the reputation and perception of the textbook among peers (mean=2.26, $\mathrm{SD}=.901$ ) and the potential value for resale (mean=2.43, $\mathrm{SD}=9.95$ ). Chi-squared analysis was done to determine if the level of importance of these factors influencing the purchase of textbooks transcended the two faculties. The only factor that varied with statistical significance was the importance of the textbook being required by the professor. Students from the Social Sciences were significantly more likely to rate the importance of a textbook being required by a professor as more important than business students $\chi^{2}(3, N=116)=0.297, p=.00$.

(Table 4: Factors Influencing Students Likelihood to Purchase Textbooks)

\section{Ease of Use}

The ease of use of textbooks across the two platforms was evaluated in relation to four main factors: the ability to install, access, navigate and read online. Students were asked to rate 
the ease of use of four features of the e-textbook from very difficult (1) to very easy (4): ability to install (Table 5). Overall, the students responded that the e-textbook was easy to use. Across the two platforms and across each of the four attributes, at least 80 percent of the respondents indicated the features were easy or very easy. The ability to read the text online was rated most difficult with students ( $18 \%$ of respondents) reporting that reading the text online was either difficult or very difficult.

In order to understand platform differences, the ability to navigate, to access, to read online, and to install/set were compared across the two platforms. There was no significant difference between the two platforms for the ability to navigate or the ability install/set up, however, the ability to access the textbook was rated significantly lower in the Flat World Knowledge textbook than the Nelson textbook $\chi^{2}(3, N=402)=16.07, p=.00$. Further, although a chi square test failed to show significance at $.05(\mathrm{p}=.08)$, a $\mathrm{p}$ value of greater than .05 but less than .1 indicates that there might be low presumption against the null hypothesis, meaning that there may be an association, but the study was underpowered to detect it and may warrant further investigation.

(Table 5: Ease of Access of Electronic Textbook)

\section{Usefulness}

$\boldsymbol{F W K}$. Students using the FWK text were asked to rate the usefulness of the various functions of their electronic textbooks including notetaking, highlighting, search function, and embedded links. Nearly half of the students did not use the highlighting, notetaking, and embedded link functions (Table 6). However the majority of those that did use these functions reported that they were useful of very useful. The ability to search within the text for specific 
words or phrases, instead of relying on an index or table of contents, was rated as the most useful feature with 66.1 percent of students rating the search feature as either useful or very useful. (Table 6: Usefulness of Electronic Textbook Features)

Nelson. In contrast to the FWK students who were asked to rate the usefulness of the functions from not useful to useful, students using the Nelson Education textbook were asked to compare the usefulness the digital format against their previous experiences in print in relation to the four functions: note taking, highlighting, and finding content ${ }^{1}$. Students were asked to consider their experience with notetaking, highlighting and finding content in print books and indicate whether the e-textbook was more useful than print textbooks, less useful than print textbooks, or if they felt there was no difference between the two formats (Figure 2). For both note taking and highlighting, students were relatively evenly split across the three groups. In contrast, the electronic textbook was overwhelmingly favoured (76.1\%) over print textbooks in its ability to assist with finding content. While table of contents and indices can be helpful to connect students with content, the ability to full text search within the digital text was reported to be overwhelmingly better favoured by students.

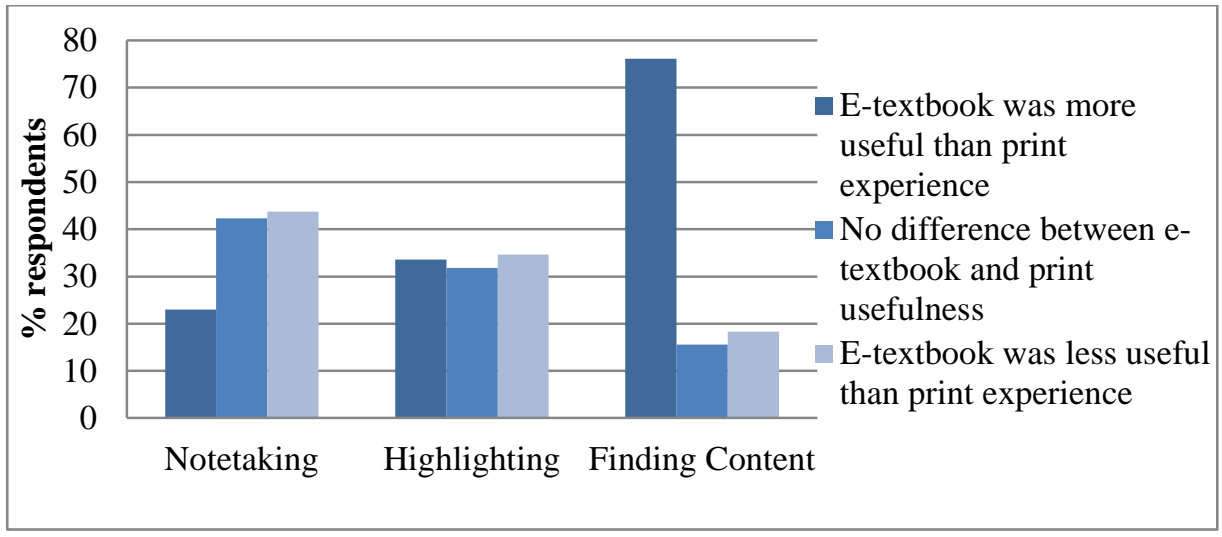

Figure 2: Usefulness of Functions in Nelson Electronic Textbook Compared to Print

\footnotetext{
${ }^{1}$ The Nelson/VitalSource platform does not provide embedded links.
} 


\section{Level of Use of the E-textbook Compared to Print}

Participants were asked to compare their level of use of the e-textbook to their previous use of print textbooks. Across both platforms, $42.4 \%$ reported using the electronic less than print textbooks in the past and only $19.1 \%$ reported their level of use of the electronic textbook as more than their previous print textbooks. Figure 3 shows the reported level of use of the electronic textbooks in each platform compared to their previous print textbooks. A chi-square test indicates that significantly more people reported a higher use of electronic textbooks compared to print when using the Nelson textbook than the Flat World Knowledge textbook $\chi^{2}(2, N=403)=0.14, p=.02$.

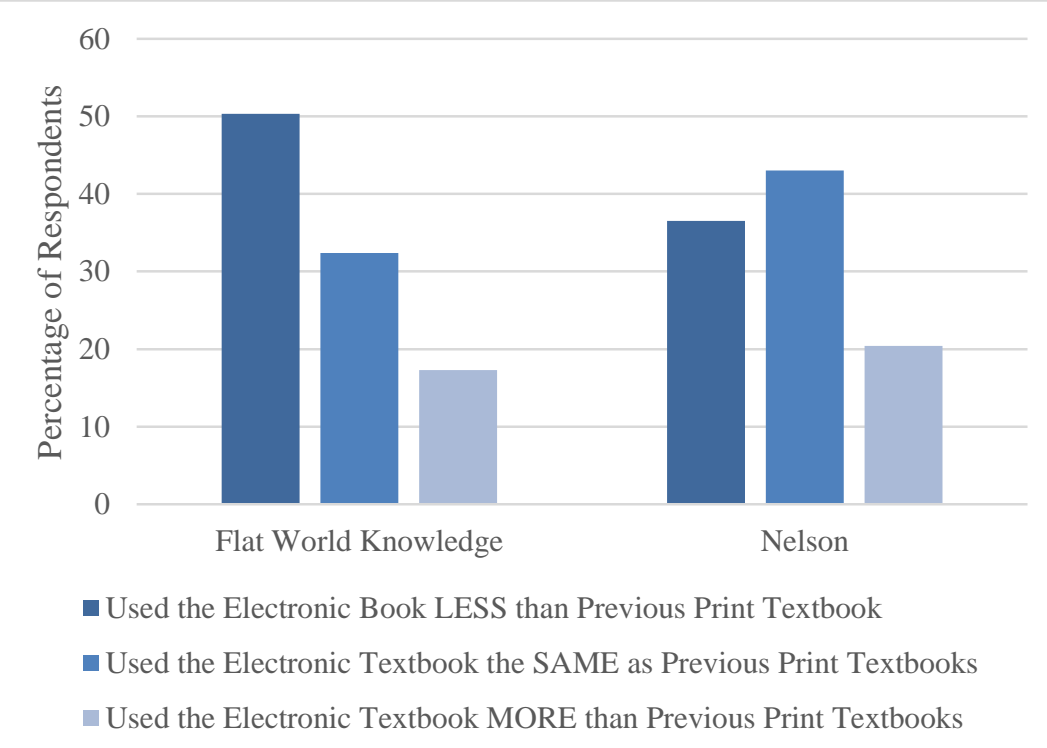

Figure 3: Comparison of Use of Electronic Textbook Again Previous Print Textbooks

It should be noted that while only three people relied on university desktop computers (in library or campus computer labs), it is worth noting that all three of these individuals indicated that they used the textbook less than print textbooks. Although the number is small, it is important to recognize that not all students have access to personal computers and that it is important that new textbook technologies are accessible and convenient for all students.

\section{Using the Print Options}


The two electronic textbook publishers gave students options for reading the textbook content in a printed format.

Flat World Knowledge. Students using the FWK textbooks were given two options for obtaining print copies of the textbook content: 1.) purchasing a full print copy of the text from the bookstore for a nominal charge of $\$ 20 \mathrm{Cdn}$, or 2.) printing specific sections from the online text (unlimited pages). Of the 173 respondents to this question, 149 students (86\%) did not purchase a print copy of the text. For the 24 students who purchased the print version, the top three reasons for making the purchase were: a general preference for print, difficulty reading and studying from e-textbook, and general preference to have access to both formats. Of the 24 respondents who purchased the print material, three quarters used the print copy rarely $(n=16)$ or never $(n=3)$.

Flat World Knowledge also gave students the ability to print chapters of the textbook from the digital format. Less than half $(43 \%, \mathrm{n}=52)$ of the respondents ever took advantage of this feature, and only 12 indicated they used this option often $(n=7)$ or always $(n=5)$.

Nelson. The users of the Nelson textbooks were also provided with two options for obtaining print copies in the Nelson textbook: 1.) purchasing the print textbook for standard textbook pricing (\$100-180) or 2.) printing specific sections of the online text, however, printing was limited to 10 pages at a time. Of the 232 respondents to this question only $26(10.4 \%)$ purchased a print copy of the textbook. Further, of the 26 who purchased the print textbook, 11 respondents indicated that they were not aware of the digital option at the time of purchase. Otherwise the top 3 reasons for purchasing a print copy of the textbook were the same three identified by students using the FWK textbook: a general preference for print, difficult reading/studying from the e-textbook, and a preference to have access to both formats. 
In addition users could print off sections of the textbook, but were restricted to printing 10 pages at a time. Of the 228 respondents to this question, 170 reported never printing out content from the electronic version (74.6\%) while 33 reported doing so rarely (14.5\%).

Students across both platforms were asked in what situations they found it most useful to read the textbook in printed format. Respondents across both platforms identified the same three situations where the print formats were most useful: note-taking, reading when studying for exams, and completing their assigned readings.

\section{Change in Level of Enthusiasm}

While students responded positively to many of the features and attributes of the electronic books, students did wane in enthusiasm from the start to the end of the pilot. Participants were asked to reflect back on their level of enthusiasm for e-textbooks when they found out that their textbook was available as an e-textbook and rate their enthusiasm on a scale from: not enthusiastic (1) to very enthusiastic (4). Participants were also then to indicate their level of enthusiasm for e-textbooks (on the same scale) following their experience of using the textbook for the semester. Twenty-seven per cent of respondents $(n=48)$ reported a decrease of one, two, or three rating points ( $21.0 \%$ and $5.4 \%$, and $1.0 \%$ respectively) and only a small minority of participants $(12 \%)$ reported an increase in enthusiasm. The mean level of enthusiasm when students found at that their textbook was available in electronic format was 3.13 , while the mean level of enthusiasm after their experience dropped to 2.92. A paired t-test of the data was conducted to compare respondents' level of enthusiasm at the end of the pilot compared to their reported level of enthusiasm when they first heard that they had access to the electronic textbook. There was a significant difference in the scores for enthusiasm following the pilot $(\mathrm{M}=2.92, \mathrm{SD}=$ $.923)$ and the scores for enthusiasm at the onset $(\mathrm{M}=3.13, \mathrm{SD}=.911)$ of the pilot $t(410)=5.383, \mathrm{p}=$ 
.00. This test indicates that there was a statistically significant drop in enthusiasm when students reflected back on their level of enthusiasm at the beginning of the pilot and considered their level of enthusiasm at the end of the pilot.

To determine whether or not this significant drop in enthusiasm was experienced on individual platforms, the same analysis was repeated for individual platforms. Across both individual platforms, respondents indicated the same drop in enthusiasm. For the Flat World Knowledge textbooks, the mean score for enthusiasm following the pilot $(\mathrm{M}=2.83, \mathrm{SD}=.906)$ was significantly lower than the mean score for enthusiasm at the onset $(\mathrm{M}=3.00, \mathrm{SD}=.844)$ of the pilot $t(175)=3.173, \mathrm{p}=.002$. For the Nelson Education textbooks, a paired t-test indicated that the mean score for enthusiasm following the pilot $(\mathrm{M}=2.99, \mathrm{SD}=.931)$ was significantly lower than the mean score for enthusiasm at the onset $(\mathrm{M}=3.23, \mathrm{SD}=.919)$ of the pilot $t(234)=4.347, \mathrm{p}=$ .00. This indicates that students experiencing a significant drop in their level of enthusiasm from the start of the pilot to the end of the pilot, independent of platform (Figure 3 and 4)

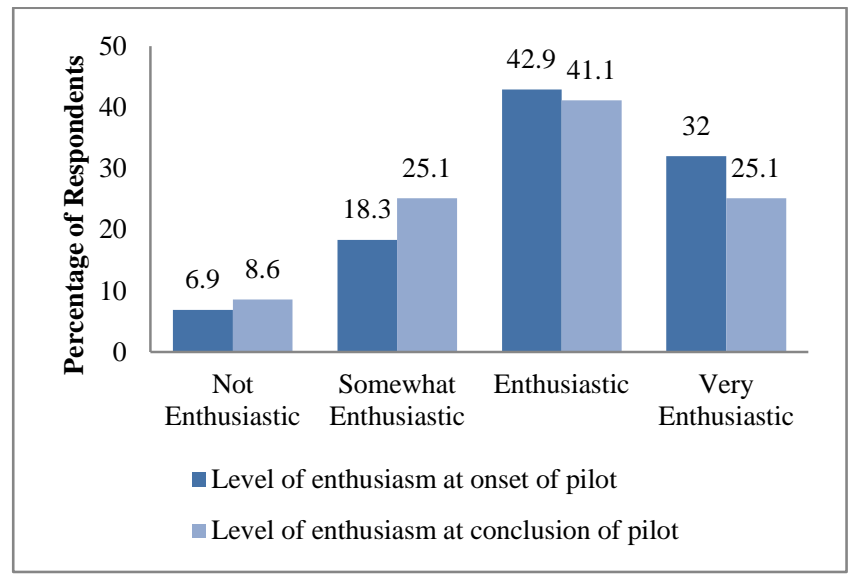

Figure 4: Flat World Knowledge Level of Enthusiasm at Onset and Conclusion of E-Textbook Pilot 


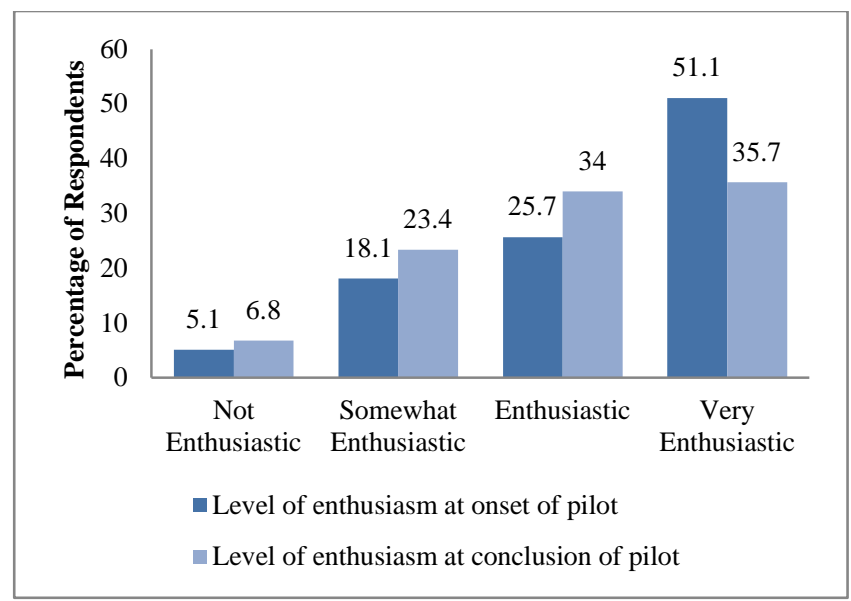

Figure 5: Flat World Knowledge Level of Enthusiasm at Onset and Conclusion of E-Textbook Pilot

\section{Limitations:}

While this study revealed many useful findings, there are limitations embedded in the study design that must be recognized. First, the findings of this study are based on students reporting and recollection of the use of the electronic textbooks and not direct observation. Second, it is not possible to determine whether differences in student experiences between the platforms could be attributed also to disciplinary differences. The differences in the textbook platform are also split along disciplinary lines. Specifically, all social sciences students used Nelson textbooks, while all but one class of business students used FlatWorld Knowledge. Thus, we were only able to report on disciplinary differences unrelated to specific experiences to the use of the textbook.

\section{Discussion:}

According to TAM, perceived ease of use, perceived usefulness and external factors contribute to the users' attitude toward using, the intention to use and ultimately the actual use of technology. Our survey used the TAM to inform what elements of student experience we should investigate to better understand actual use behavior by students. 
The perceived ease of use across of electronic textbooks from Flat World Knowledge and Nelson Education was high with at least 80 percent of the respondents reporting that the textbooks' ability to install access, navigate, and read online was easy or very easy. Not surprisingly, the ability to read online was rated the lowest. The challenge of reading online is a commonly cited deficit of e-textbooks (Bennett and Landoni, 2005; Foasberg, 2011; Johnson and Buck, 2014; Kang, et al., 2009). Although our research failed to show that Nelson was statistically less easy to read online, the research does suggest that further investigation is warranted. A review of the open comments suggest that the challenges of reading online centered around the platform's layout, session time-outs, and the limitations on exporting to an external format like PDF. The struggle with readability continues to confirm previous research that some users find it more difficult to read electronic formats compared to print.

While the ease of use was rated similarly across platforms, the ability to access the textbook was rated significantly lower in the case of Flat World Knowledge than the Nelson. Initial access to the FWK textbook did require users to undergo additional steps to redeem their access code as a result of professors using different versions of the textbook with individual customizations for their sections. This finding reinforces students' desire for streamlined and simple access to electronic resources (Kline and Williams, 2008).

The usefulness of e-textbooks' highlighting, note taking and searching features were positively evaluated. While not all students made use of these functions, the majority of students who did make use of these features reported that they were useful or very useful. In addition, users of both the FWK and Nelson textbooks gave very positive reviews to searching in electronic textbooks. 
When students are provided with the electronic textbook they appear to be willing and able to easily make use of the content and functions. Students' ability and acceptance or willingness to make use electronic textbooks is also evidenced by the low uptake of print options by students. Despite the fact that print versions of the textbooks were available in variety of ways, either through economical purchasing or printing sections of the book, the vast majority of students in this study chose not to take advantage of these print alternatives. However, it is very concerning that almost half of all respondents reported using the electronic textbook less than they used previous print textbook. In consideration that overall the usefulness and ease of use is rated highly, more investigation into what contributes to the decrease in students' use must be done.

In addition to ease of use and usefulness, TAM also recognizes the role of external factors on technology adoption. Cost has been identified as a key external factor in students' electronic textbook adoptions (Chulkov and VanAlstine, 2013, 2014; Terpend et al., 2014). In the current study, the pilot was able to provide students with a free electronic textbook, and therefore cost was removed as a factor. While this allowed the study to focus on ease of use and usefulness, it is important that this is a key issue for students. Cost was the second most important factor influencing students' likelihood to purchase a textbook (following requirement by professor). In the open comments of the survey, maintaining the textbook at a low or no cost was an overwhelming theme. As such, if textbook costs were more affordable than print, acceptance and uptake of e-textbook may great increase. Our study evaluated both an affordable, previous open, textbook provider as well as a costly traditional publisher. Students' experiences with the two different textbook publishers did not greatly vary. In fact, while FWK's ability to access was rated more difficult, the ability to read trended towards being easier in the FWK 
textbooks. The evaluation of usefulness between the textbooks was very similar. The benefit to using a commercial publisher is the breadth of options that faculty are able to access which align their current curriculum, however our study suggests that students' experiences are not that different when using a less commercial, less flashy, and less expensive options.

In spite of the overall positive findings of many features of the textbook, the drop in enthusiasm throughout the duration of the pilot is intriguing and requires more investigation. The drop in enthusiasm may be attributed to the high expectations for e-textbooks. While overall the students rated the ease of use and usefulness as positive, the e-books may not have met the initial expectations for the technology. When adopting new technologies we have become accustomed to seamless experiences with products to simplify procedures. E-textbooks are competing with its predecessor product, print textbooks, which are extremely comfortable and familiar to users. E-textbooks may complicate the simple procedure of opening and reading a textbook (Kline and Williams, 2008). While students may not readily recognize it, the reading experience can be more difficult, and interacting with the textbook in more complex ways does require some learning on the user's part.

Previous research has focused on and highlighted students' preference as a measure of acceptance of e-textbooks and has not delved into what the TAM labels actual use when given the e-textbook for use. The current study highlights that while research suggests that students prefer for print over electronic in some contexts, provided with an e-textbook and the option to take advantage of print alternatives, students rarely acted on that preference by seeking out alternative print options.

\section{Suggestions for Future Research}


While this study gives a snapshot of the experiences of students using electronic textbooks, it also highlights the need for further research on both e-texbook usage, as well as the e-textbook publishing environment.

Given the recognized limitations of our study, future research is needed expanding the disciplines of study, as well as expanding the platforms for electronic books in order to better understand the potential differences across platforms, disciplines and courses.

Our pilot was particularly interested in exploring open-access options in the textbook market. FWK ceased providing open access to their textbook library during our pilot, however, other open-textbook initiatives are being explored such as the provincial open textbook initiative in British Columbia (Broughton, 2013). The current research indicates that student experiences with more affordable options is very comparable and supports further research and pilots to assess the feasibility of these models. Affordable or open textbooks have the potential to ease the burden on students in a difficult financial climate. Further, our results for ease of use and usefulness indicated that student are quite positive about electronic textbooks but the challenges that did arise may be attributed in part to the tight control necessary for DRM. As such, further assessment the impact of digital right management (DRM) on student experience would be beneficial.

Further, much of the research into the electronic textbooks has focused on preference, rather than actual behaviour and use. By examining actual use, it is possible that reported preference and actual use may diverge, perhaps due in part to external factors.

\section{Conclusion}

The electronic textbook environment is changing rapidly and university and colleges are aggressively exploring electronic textbooks as a primary format for textbook delivery. The 
current research suggests that while electronic textbooks may not be meeting the high expectations of students, student's preference for certain features of print textbooks is limited in determining their actual use behaviour when provided with textbooks in electronic format. Given the central role that textbooks play in students' post-secondary education learning experience, we must continue to study how this new technology impacts their experience and strive to be advocates for better electronic textbooks that can truly fulfill the promise that many see in this growing arena. 


\section{References}

Allen, N. (2009), "High tech textbooks: a snapshot of student opinions", The Student PIRGs,. Available at: http://www.washpirgstudents.org/sites/student/files/resources/high-techtextbooks. pdf (accessed October 2014).

Bennett, L., and Landoni, M. (2005), "E-books in academic libraries", The Electronic Library, Vol. 23 No. 2, pp. 9-16.

Berg, S. A., Hoffmann, K., and Dawson, D. (2010). "Not on the same page: undergraduates' information retrieval in electronic and print books", The Journal of Academic Librarianship, Vol. 36 No. 6, pp. 518-525.

Blummer, B., and Kenton, J. (2012), "Best practices for integrating e-books in academic libraries: a literature review from 2005 to present", Collection Management, Vol. 37 No. 2, pp. 65-97.

Broughton, C. (2013), “Open Textbooks: learning from our WA neighbours”, BC Campus OpenED. Available at: http://open.bccampus.ca/2013/02/18/open-textbooks-learningfromour-wa-neighbours (accessed April 2014).

Campus Technology. (2012). "National Federation of the Blind Takes On E-Text Pilots", available at http://campustechnology.com/Articles/2012/10/02/National-Federation-oftheBlind-Takes-On-EText-Pilots.aspx?Page=1 (accessed 8 January 2015)

Chesser, W. D. (2011), “The e-textbook revolution” In: Sue Polanka (Ed.), The No Shelf Required Guide to E-book Purchasing, Chicago, ALA TechSource, pp. 28-40.

Chulkov, D. V., and VanAlstine, J. (2013), "College student choice among electronic and printed textbook options", Journal of Education for Business, Vol. 88 No. (4), pp. 216-222.

Chulkov, D. V., and VanAlstine, J. (2014), "The impact of multiple textbook format availability in business education", Journal of Applied Research in Higher Education, Vol. 6 No. 1, pp. 176-186.

CourseSmart. (2013) "CourseSmart Fall 2013 Research Project”, available at: http://www.coursesmart.com/go/fall2013research, (accessed 8 January 2015)

Davis, F. D., Bagozzi, R. P., and Warshaw, P. R. (1989), "User acceptance of computer technology: a comparison of two theoretical models", Management science, Vol. 35 No. 8, pp. 982-1003.

de Oliveira, S. M. (2012), "E-textbooks usage by students at Andrews University: A study of attitudes, perceptions, and behaviors", Library Management, Vol. 33 No. 3, pp. 536-560.

Edmunds, R., Thorpe, M., and Conole, G. (2012), "Student attitudes towards and use of ICT in 
course study, work and social activity: A Technology Acceptance Model approach", British Journal of Educational Technology, Vol. 43 No. 1, pp. 71-84.

Foasberg, N. M. (2011). “Adoption of e-book readers among college students: A survey”, Information Technology and Libraries, Vol 30 No. 3, pp. 108-128.

Foasberg, N. M. (2014). "Student reading practices in print and electronic media", College and Research Libraries, Vol. 75 No. 5, pp. 705-723.

Hilton, J. III, Robinson, T. J., Wiley, D., and Ackerman, J. D. (2014), "Cost-savings achieved in two semesters through the adoption of open educational resources", The International Review of Research in Open and Distance Learning, Vol. 15 No. 2, Available at: http://www.irrodl.org/index.php/irrodl/article/view/1700.

Hilton, J. III and Wiley, D. A. (2010), “A sustainable future for open textbooks? The Flat World Knowledge story", First Monday, Vol. 15 No. 8, Available at:

http://firstmonday.org/ojs/index.php/fm/article/view/2800/2578.

Howard, J. (2012), "Flat World Knowledge to drop free access to textbooks", The Chronicle of Higher Education, Available at http://chronicle.com/blogs/wiredcampus/flatworldknowledgeto-drop-free-access-to-textbooks/40780, (Accessed 15 January 2013).

Internet2 (2012). “eTextbook spring 2012 pilot: final project report", available at: http://www.internet2.edu/media/medialibrary/2013/10/07/eText-Spring-2012-PilotReport.pdf, (accessed 30 October 2014)

Jeong, H. (2012), "A comparison of the influence of electronic books and paper books on reading comprehension, eye fatigue, and perception", The Electronic Library, Vol. 30 No. 3, pp. 390-408.

Johnson, G. M., and Buck, G. H. (2014), "Electronic books versus paper books: pre-service teacher preference for university and recreation reading", International Journal of Humanities, Social Sciences and Education, Vol. 1 No. 8, pp. 13-22.

Kang, Y. Y., Wang, M. J. J., and Lin, R. (2009), "Usability evaluation of e-books", Displays, Vol. 30 No. 2, pp. 49-52.

Kline, E., and Williams, B. (2008), "Managing users' expectations of e-books", The Acquisitions Librarian, Vol. 19 No. 3-4, pp. 409-415.

Lyons, C. and Hendrix, D. (2014), "Textbook affordability: is there a role for the library", The Serials Librarian, Vol. 66, pp. 262-267.

Parsons, K. M. (2014), "What are they yhinking? Dental assisting students' feelings about ebooks", TechTrends, Vol. 58 No. 2, pp. 78-86.

Robinson, S. (2011), "Student use of a free online textbook", Academy of Educational 
Leadership Journal, Vol. 15 No. 3, pp. 1-10.

Reynolds, R. (2011), "Have digital textbooks reached the tipping point in higher education?", working paper, Xplana, Available at:

http://info.xplana.com/report/pdf/Xplana_Whitepaper_2011.pdf, (Accessed November 2014).

Shelburne, W. A. (2009), "E-book usage in an academic library: user attitudes and behaviors", Library Collections, Acquisitions, and Technical Services, Vol. 33 No. 2-3, pp. 59-72.

Shepperd, J. A., Grace, J. L. and Koch, E. J. (2009), "Evaluating the electronic textbook: is it time to dispense with the paper text?", Teaching of Psychology, Vol. 35 No. 1, pp. 2-5.

Shih, B. Y., Shih, C. H., Li, C. C., Chen, T. H., Chen, Y. H., and Chen, C. Y. (2011), "Elementary school students acceptance of Lego NXT: the technology acceptance model, a preliminary investigation", International Journal of Physical Sciences, Vol. 6 No. 22, pp. 5054-5063.

Shroff, R. H., Deneen, C. D., and Ng, E. M. (2011), "Analysis of the technology acceptance model in examining students' behavioural intention to use an e-portfolio system", Australasian Journal of Educational Technology, Vol. 27 No. 4, pp. 600-618.

Simba Information. (2012), "eTextbooks and multimedia in higher education 2012", The Market Publishers, Ltd., Available at: http://www.simbainformation.com/eTextbooksMultimedia-Higher-7114152/, (Accessed 3 April 2013)

Sun, J., Flores, J., and Tanguma, J. (2012), "E-textbooks and students' learning experiences", Decision Sciences Journal of Innovative Education, Vol. 10 No. 1, pp. 63-77.

Terpend, R., Gattiker, T. F., and Lowe, S. E. (2014), "Electronic textbooks: antecedents of students' adoption and learning outcomes", Decision Sciences Journal of Innovative Education, Vol. 12 No. 2, pp. 149-173.

Venkatesh, V., Morris, M. G., Davis, G. B., and Davis, F. D. (2003), "User acceptance of information technology: toward a unified view", MIS quarterly, pp. 425-478.

Woody, W. D. Daniel, D. B. and Baker, C. A. (2010), "E-books or textbooks: students prefer textbooks", Computers and Education, Vol. 55 No. 3, pp. 945-948. 


\begin{tabular}{|c|c|c|c|c|c|}
\hline Discipline & $\begin{array}{l}\text { Section/ } \\
\text { Classes }\end{array}$ & Platform & Textbook Title & $\begin{array}{c}\# \\
\text { Enrolled }\end{array}$ & $\begin{array}{c}\# \text { of } \\
\text { Respondents } \\
(\%)\end{array}$ \\
\hline $\begin{array}{l}\text { Business } \\
\text { (Business) }\end{array}$ & 6 & FWK & $\begin{array}{l}\text { Information Systems: A Manager's } \\
\text { Guide to Harnessing Technology }\end{array}$ & 255 & $175(69 \%)$ \\
\hline $\begin{array}{l}\text { Psychology } \\
\text { (Social Sciences) }\end{array}$ & 2 & Nelson & $\begin{array}{l}\text { Abnormal Child Psychology, 5th } \\
\text { Edition }\end{array}$ & 267 & $119(44 \%)$ \\
\hline $\begin{array}{l}\text { Labor Studies } \\
\text { (Social Sciences) }\end{array}$ & 1 & Nelson & $\begin{array}{l}\text { Work, Industry, and Canadian } \\
\text { Society, 6th Edition }\end{array}$ & 91 & $26(26 \%)$ \\
\hline $\begin{array}{l}\text { Gen Social } \\
\text { Sciences } \\
\text { (Social Sciences) }\end{array}$ & 1 & Nelson & Statistics Unplugged, 4th Edition & 201 & $59(30 \%)$ \\
\hline $\begin{array}{l}\text { Business } \\
\text { (Business) }\end{array}$ & 1 & Nelson & $\begin{array}{l}\text { Entrepreneurship: Theory, Process } \\
\text { and Practice, } 9 \mathrm{th} / \mathrm{Ed}\end{array}$ & 57 & $37(64 \%)$ \\
\hline
\end{tabular}

Table 1: Courses, Textbooks, and Response Rate

\begin{tabular}{|l|l|l|}
\hline Age of Respondents & Year of Program & Sex \\
\hline Range $=19-50$ years & Year $1=9 \%$ & Male $40 \%$ \\
Mean $=22.5$ years & Year $2=46 \%$ & Female $60 \%$ \\
Mode $=21$ years & Year $3=26 \%$ & \\
& Year $4=16 \%$ & \\
& Not Applicable $=3 \%$ &
\end{tabular}

Table 2: Respondent Demographics

\begin{tabular}{|lccc|}
$\begin{array}{l}\text { Please rate your level of } \\
\text { comfort with computer } \\
\text { technologies }\end{array}$ & $\begin{array}{c}\text { All Respondents } \\
\text { Comfortable }\end{array}$ & $\begin{array}{c}\text { Respondents from Faculty of } \\
\text { Business* }\end{array}$ & $\begin{array}{c}\text { Respondents from Faculty } \\
\text { of Social Sciences } \\
\%\end{array}$ \\
& $68.3 \%$ & $(\mathbf{n})$ & $(\mathbf{n})$ \\
\hline Somewhat Comfortable & $(24)$ & $52.0 \%$ & $80.1 \%$ \\
& $26.4 \%$ & $(91)$ & $(193)$ \\
\hline Not at all Comfortable & $(110)$ & $36.6 \%$ & $19.1 \%$ \\
& $4.3 \%$ & $(64)$ & $.86)$ \\
\hline
\end{tabular}

Table 3: Reported Level of Comfort with Technology

\begin{tabular}{llccc}
\hline & & Combined & Social Sciences & Business \\
\hline Requirement of & Not at all important & $0.7 \%$ & $0 \%$ & $1.4 \%$ \\
Professor & Somewhat important & $11.4 \%$ & $5.0 \%$ & $17.5 \%$ \\
& Important & $39.3 \%$ & $32.8 \%$ & $45.5 \%$ \\
& Very important & $48.5 \%$ & $62.2 \% *$ & $35.5 \% *$ \\
Cost of Textbook & Mean & 3.36 & 3.57 & 3.15 \\
& Not at all important & $5.3 \%$ & $5.0 \%$ & $5.7 \%$ \\
& Somewhat important & $16.3 \%$ & $14.9 \%$ & $17.5 \%$ \\
& Important & $31.8 \%$ & $29.4 \%$ & $34.1 \%$ \\
Textbook & Very important & $46.6 \%$ & $50.7 \%$ & $42.7 \%$ \\
& Mean & 3.20 & 3.26 & 3.14 \\
\hline
\end{tabular}




\begin{tabular}{llccc}
\hline Reputation & Somewhat important & $39.8 \%$ & $39.3 \%$ & $40.3 \%$ \\
& Important & $29.4 \%$ & $28.4 \%$ & $30.3 \%$ \\
& Very important & $9.2 \% \%$ & $7.5 \%$ & $10.9 \%$ \\
Potential for Future & Mean & 2.26 & 2.18 & 2.34 \\
\cline { 2 - 2 } & Not at all important & $13.1 \%$ & $10.0 \%$ & $16.1 \%$ \\
& Somewhat important & $37.1 \%$ & $39.3 \%$ & $35.1 \%$ \\
& Important & $31.6 \%$ & $32.3 \%$ & $30.8 \%$ \\
& Very important & $18.2 \%$ & $18.4 \%$ & $18.0 \%$ \\
& Mean & 2.55 & 2.59 & 2.51 \\
Interest in Subject & Not at all important & $14.6 \%$ & $16.9 \%$ & $12.3 \%$ \\
& Somewhat important & $35.4 \%$ & $31.3 \%$ & $39.3 \%$ \\
& Important & $35.2 \%$ & $35.3 \%$ & $35.1 \%$ \\
Potential for Resale & Not at all important & $14.8 \%$ & $16.4 \%$ & $13.3 \%$ \\
Value & Mery important & 2.50 & 2.51 & 2.49 \\
& Somewhat important & $32.5 \%$ & $21.4 \%$ & $19.9 \%$ \\
& Important & $30.3 \%$ & $35.8 \%$ & $29.4 \%$ \\
& Very important & $16.5 \%$ & $26.9 \%$ & $33.6 \%$ \\
& Mean & 2.43 & $15.9 \%$ & $17.1 \%$ \\
\hline
\end{tabular}

Table 4: Factors Influencing Students Likelihood to Purchase Textbooks

\begin{tabular}{llccc}
\hline & & Combined & $\begin{array}{c}\text { Flat World } \\
\text { Knowledge }\end{array}$ & Nelson \\
\hline Ability to access & Very difficult & $.5 \%$ & $1.2 \%$ & $0 \%$ \\
& Difficult & $5.5 \%$ & $8.1 \%$ & $3.5 \%$ \\
& Easy & $59.2 \%$ & $65.3 \%$ & $54.6 \%$ \\
& Very easy & $34.8 \%$ & $25.4 \%$ & $41.9 \% *$ \\
& Mean & 3.28 & 3.15 & 3.38 \\
\hline \multirow{2}{*}{ Ability to install } & Very difficult & $1.0 \%$ & $1.2 \%$ & $.9 \%$ \\
& Difficult & $7.0 \%$ & $5.8 \%$ & $7.9 \%$ \\
& Easy & $58.7 \%$ & $63.0 \%$ & $55.5 \%$ \\
& Very easy & $33.3 \%$ & $30.1 \%$ & $35.8 \%$ \\
Ability to Navigate & Mean & 3.24 & 3.22 & 3.14 \\
through e- & Very difficult & $1.2 \%$ & $.6 \%$ & $1.7 \%$ \\
Textbook & Difficult & $10.4 \%$ & $11.5 \%$ & $9.6 \%$ \\
& Easy & $59.4 \%$ & $63.8 \%$ & $55.5 \%$ \\
Ability to read & Very easy & $29.3 \%$ & $24.1 \%$ & $33.2 \%$ \\
online & Mean & 3.16 & 3.11 & 2.34 \\
& Very difficult & $2.7 \%$ & $2.3 \%$ & $3.1 \%$ \\
& Difficult & $15.9 \%$ & $17.9 \%$ & $14.4 \%$ \\
& Easy & $54.2 \%$ & $59.0 \%$ & $50.7 \%$ \\
& Very easy & $27.1 \%$ & $20.8 \%$ & $31.9 \%$ \\
\hline
\end{tabular}

Table 5: Ease of Access of Electronic Textbook

\begin{tabular}{llc}
\hline Notetaking & Did not use & $\mathbf{5 1 . 1 \%}$ \\
& Not useful & $\mathbf{5 . 2 \%}$ \\
& Somewhat useful & $\mathbf{1 0 . 9 \%}$ \\
& Useful & $\mathbf{2 4 . 1 \%}$ \\
\hline
\end{tabular}




\begin{tabular}{llc}
\hline & Very useful & $\mathbf{8 . 6 \%}$ \\
\hline Highlighting & Did not use & $45.4 \%$ \\
& Not useful & $5.2 \%$ \\
& Somewhat useful & $11.5 \%$ \\
& Useful & $25.3 \%$ \\
& Very useful & $12.6 \%$ \\
Finding Content & Did not use & $17.8 \%$ \\
(Search) & Not useful & $3.4 \%$ \\
& Somewhat useful & $12.6 \%$ \\
& Useful & $31.0 \%$ \\
& Very useful & $35.1 \%$ \\
Embedded links & Did not use & $43.7 \%$ \\
& Not useful & $4.6 \%$ \\
& Somewhat useful & $23.0 \%$ \\
& Useful & $19.0 \%$ \\
& Very useful & $9.8 \%$ \\
\hline
\end{tabular}

Table 6: Usefulness of Electronic Textbook Features 